\title{
フタロシアニン粒子分散型光電池の光電変換 挙動と色素前処理の効果
}

\author{
南 信次*1 ・佐々木 寛治*1
}

(受付 1982 年 11 月 1 日・篦查終了 1982 年 11 月 12 日)

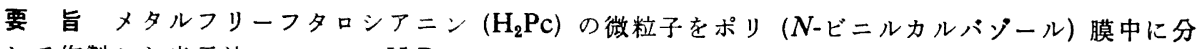
散して作製した光電池について， $\mathrm{H}_{2} \mathrm{Pc}$ の種々の前処理か，光電変換特性に及ぼす影響を調べた。硫 酸からの再沈殿あるいは年華精製をした $\mathrm{H}_{2} \mathrm{Pc}$ を用いた場合, 短絡光電流密度 $\left(J_{\mathrm{Bc}}\right)$ 及びエネルギ 一変換効率 $(\eta)$ が末処理の $\mathrm{H}_{2} \mathrm{Pc}$ よりも低下した。これは， $\mathrm{H}_{2} \mathrm{Pc}$ の粒度が，再沈殿や年華によっ て粗くなるためであった， $\mathrm{H}_{2} \mathrm{Pc}$ をボールミルすることによって，J $J_{\mathrm{sc}}, \eta$ ともに向上した。一方，末 処理 $\mathrm{H}_{2} \mathrm{Pc}$ に含まれる不純物は, 强光下での電子とホールの再結合や光電池性能の経時劣化化関与乙 ていることが示唆された。蒸着膜光電池に比べ, 粒子分散膜光電池の効率が高いことから, $\mathrm{H}_{2} \mathrm{Pc}$ 粒 子表面が光キャリア発生に重要であることがわかった。
\end{abstract}

\section{1 緒言}

太陽電池が，宇宙用など特殊な用途だけでなく，一般 電力用として利用できるようになるには、コストダウン が必須の条件である.そのため, $\mathrm{Si}$ 単結晶製造の低コス 卜化, 多結晶やアモルファス $\mathrm{Si}$ 太陽電池などの開発が 急がれている11,2)。一方，これまで太陽電池用としては ほとんど注目されなかった材料も取り上げられるよらに なってきた．有機材料を用いた太陽電池の研究もその一

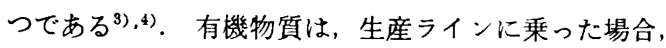
大量かつ安価に供給できることから潜在的に材料コスト が安いままた加工しやすいことも大きな特長であり，材 料, 加工の両面でコストダウンに寄与できる可能性があ る.

我々は, 化学的に安定でしかも安洒，無公害と考えら れるフタロシアニンを材料として選び，その光電変換機

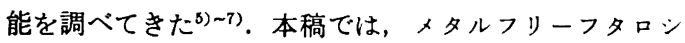
アニン $\left(\mathrm{H}_{2} \mathrm{Pc}\right)$ の微粒子を高分子パインダー膜中に分散 して作製した乾式光電池について報告する. この方法 は，従来有機色素薄膜の作製に広く用いられてきた真空 蒸着法と比べると, 真空装置が不要で極めて簡便である こと，熱を加えないので熱分解の心配かないこと，素子 面積を大きくすることが原理的に容易であり太陽光利用 に有利であること，ハインダーにより剥離しにくい丈夫 な膜が得られることなど，有機材料の持つ特長を生かし た技術と考えられる. また，電子材料としての高分子の 用途開拓といら観点からも, 将来への発展が期待される

* 瀻維高分子材料研究所

(画305 茨城県筑波郡谷田部町東 1-1-4)
分野である.

この種の光電池については, カナダのゼロックス社の グループが精力的な研究を行っており, 基礎的な物性も

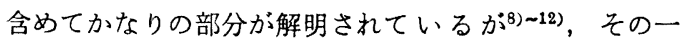
方で，製造上の know-how について明らかでない点も 多い，本報告では，素子製造上の諸条件，特に $\mathrm{H}_{2} \mathrm{Pc}$ 前 処理が素子性能に与える影響について述へ，更に蒸着膜 光電池との比較を行う. それらの結果から, この種の光 電池に扑ける光キャリアの発生機構について考察を加え る.

\section{2 実験}

\section{1 材料}

用いた $\mathrm{H}_{2} \mathrm{Pc}$ は，東京化成工業 (株)製のもの，及びそ れに種々の前処理を施したものである. 前処理として は, 昇華精製, 硫酸溶液からの再沈殿 (acid pasting), 及びボールミルを行った。

昇華精製は，石英管 $\left(30^{\phi} \times 500 \mathrm{~mm}\right)$ の中に未処理 $\mathrm{H}_{2} \mathrm{Pc}$ をのせた石英ボートを入れ，アルゴン気流 200〜 $300 \mathrm{~Pa}, 400 \sim 450^{\circ} \mathrm{C}$ において行った。 これには，管状 電気炬を用いた。昇華精製を 3 回繰り返したものをアセ トンで洗浄して用いた，最初の昇華では仕込み量の13重 量\%にあたる非昇華残余物があったが， 2 回目以降は 残余物はほとんどなかった。これは $\mathrm{H}_{2} \mathrm{Pc}$ 合成過程で混 入した不純物と思われる.

硫酸処理は, $0^{\circ} \mathrm{C}$ に冷却した濃硫酸に未処理 $\mathrm{H}_{2} \mathrm{Pc}$ を 溶解したものをガラスロートで濾過し，濾液を氷水中に 注いで再沈沮させることによって行った。この後, 沈殿 物をイソプロピルフルコール及びアセトンで洗浄した。 
南・佐々木

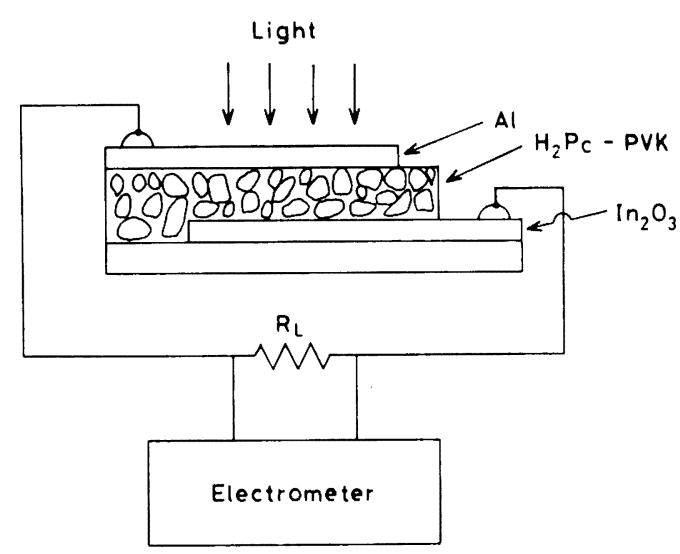

Fig. 1. Side view of an $\operatorname{In}_{2} \mathrm{O}_{3} / \mathrm{H}_{2} \mathrm{Pc}-\mathrm{PVK} / \mathrm{Al}$ cell.

ボールミルは, 昇華精製した $\mathrm{H}_{2} \mathrm{Pc}$, あるいは硫酸処 理した $\mathrm{H}_{2} \mathrm{Pc}$ を、ステンレスボールとともに, ステンレ スカプセルに入れ，8の字形に激しく振動させることに より行った.これには, Spex 5100 型ミキサーミルを用 いた.

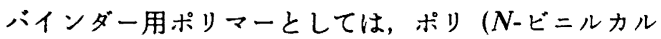
バゾール) (PVK，東京化成工業(株)製)を用いた。 また， キャスト膜作製などのための溶媒は，すべて市販の試薬 特級のものをそのまま用いた.

キャスト膜の基板には，酸化インジウム $\left(\operatorname{In}_{2} \mathrm{O}_{3}\right)$ から 成る透明導電ガラス（松崎真空被膜 (株) 製) を $33 \times 25$ $\mathrm{mm}^{2}$ の大きさに切り出して用いた. リード線を固定す る便宜上, $\operatorname{In}_{2} \mathrm{O}_{3}$ 被膜の一部を塩酸エッチングにより取 り除いた。

\section{2 光電池作製法}

透明導電ガラスは，加熱した実験用中性洗剂に浸し超 音波洗浄した後, 流水, 及び蒸留水で十分にすすいでか ら用いた.

$\mathrm{H}_{2} \mathrm{Pc}$ と PVK $20 \mathrm{mg}$ 対 $14 \mathrm{mg}$ の重量比で前述 のステンレスカプセルに入れ，それにトルェンとシクロ ヘキサノンの 1 対 1 混合溶媒を $1 \mathrm{ml}$ 加えた. これを, 前述のミキサーミルを用いて数時間混合し, 生成したス ラリー状のものを基板上に滴下し，スピンナー（ミカサ (株)製 1H-D 2 型）を用いてキャスト製膜した。溶媒を

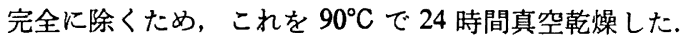

$\mathrm{H}_{2} \mathrm{Pc}$ 真空蒸着膜は, タングステンヒーターを巻いた フルミナるつぼに $\mathrm{H}_{2} \mathrm{Pc}$ 粉末を入れ， $10^{-3} \mathrm{~Pa}$ の真空中 で加熱蒸発させて作製した.

Talystep 1 (Rank Taylor Hobson 社製) を用いて 分散膜表面の形状を調べたところ， $\mathrm{H}_{2} \mathrm{Pc}$ 粒子による凹 凸が激しいことがわかった，平均的膜厚が $0.7 \mu \mathrm{m}$ 程度 であるのに対し，大きいもので $1 \sim 2 \mu \mathrm{m}$ ぐらいの粒子が
分散していた。

$\mathrm{H}_{2} \mathrm{Pc}$ 分散膜あるいは蒸着膜の上に, フルミニウムを 真空蒸着して対極とした. $\mathrm{Al}$ 膜の可視光透過率は 6〜 $10 \%$, 電極の有効面積は $0.45( \pm 0.1) \mathrm{cm}^{2}$ である.

\section{3 測定法}

Fig. 1 に示すように, $\mathrm{A} 1, \mathrm{In}_{2} \mathrm{O}_{3}$ 両極に銀ペーストを 塗って，クリップによりリード線を固定した. 両極間に 負荷抵抗 $R_{\mathrm{L}}$ をつなぎ，光照射に伴う $R_{\mathrm{L}}$ 両端の電圧 変化を光電応答として検出した．測定には，ディジタル エレクトロイーター (Keithley 社製 616 型) を用いた。

$150 \mathrm{~W}$ ハロゲンランプの光を, 赤外カットフィルター (東芝 (株) 製 IRA-25S), 干渉フィルター (日本真空光学 (株)製 IF-S) を通して単色光とし，試料に照射した．変 換効率などの評価は，すべて $\mathrm{H}_{2} \mathrm{Pc}$ の吸収ピークである $617 \mathrm{~nm}$ で行った. 光強度はニュートラルデンシティフ ィルターにより調節した. 光電流スペクトルは, 400〜 $800 \mathrm{~nm}$ の範囲で干渉フィルターを交換して測定した。 各波長における光強度は, 光パワーメーター (Laser Instrumentation 17 型)により測定し，光電流実測值を一 定フォトン数に対する值となるよう補正した。

暗中での電流電圧特性の測定では, ファンクションシ ェネレーター (Wavetek 社製 145 型) からの3 角波を 試料に印加し, 電流測定用に前述のエレクトロメーター を用いて，それぞれからの出力をXYレコーダー（横河 電機製作所(株) 3078 型) 上に記録した.

$\mathrm{H}_{2} \mathrm{Pc}-\mathrm{PVK}$ 膜の吸収スペクトル, $\mathrm{Al}$ 電極の透過率 は, Cary 17DX 自記分光光度計により測定した. 本報 告でいら入射光強度 $\left(P_{\mathbf{I n}}\right)$ は, すべて $\mathrm{Al}$ 膜の透過率を 補正した値, すなわち色素層に入射した光の強度であ る.

\section{3 結果と考察}

\section{1 光電池としての一般特性}

この光電池は常に $\mathrm{A} 1$ 側が負の光電応答を生じた. $R_{\mathrm{L}}$ の大きさを順次変えながら電流対電圧をプロットするこ とにより，Fig. 2 のような光電流電圧曲線が得られた. $R_{\mathrm{L}} \leq 10^{5} \sim 10^{8} \Omega$ では短絡光電流 $\left(I_{\mathrm{Bc}}\right)$ が, $R_{\mathrm{L}} \geq 10^{8} \Omega$ で は開放電圧 $\left(V_{\text {oc }}\right)$ が生じているとみなせる. Fig. 2 で は, $V_{\mathrm{oc}}=0.7 \mathrm{~V}, I_{\mathrm{sc}}=30 \mathrm{nA}$ である.

最適動作電圧 $\left(V_{\mathrm{op}}\right)$, 最適動作電流 $\left(I_{\mathrm{op}}\right)$ は, 電圧と電 流の積 (すなわち電力) が最大となる点から求まる (Fig. 2 の斜線部). Fig. 2 では $V_{\mathrm{op}}=0.5 \mathrm{~V}, I_{\mathrm{op}}=16 \mathrm{nA}$ で ある. エネルギー変換効率 $(\eta)$ は, 次式で与えられる.

$$
\eta(\%)=\frac{V_{\mathrm{op}} \times I_{\mathrm{op}}}{P_{\mathrm{ln}} \times A} \times 100=\frac{V_{\mathrm{oc}} \times I_{\mathrm{sc}} \times F F}{P_{\mathrm{ln}} \times A} \times 100 .
$$

ここで $P_{\mathrm{In}}$ は, 入射光強度の密度, $A$ は有効電極面積 である. $F F$ は曲線因子 (Fill Factor) と呼ばれ， $V_{\text {oc }} \times$ $I_{\mathrm{sc}}$ に対する $V_{\mathrm{op}} \times I_{\mathrm{op}}$ の比を示す量である. Fig. 2 で 


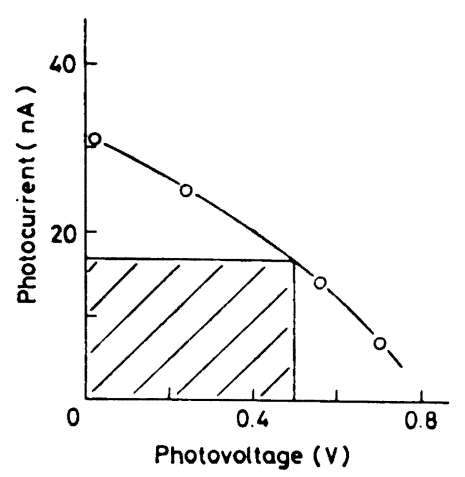

Fig. 2. Photocurrent-photovoltage curve of an $\mathrm{In}_{2} \mathrm{O}_{3} / \mathrm{H}_{2} \mathrm{Pc}-\mathrm{PVK} / \mathrm{Al}$ cell whose electrode area was $0.47 \mathrm{~cm}^{2}$. Light intensity $\left(P_{1 \mathrm{n}}\right)=2.2 \mu \mathrm{W} / \mathrm{cm}^{2}$.

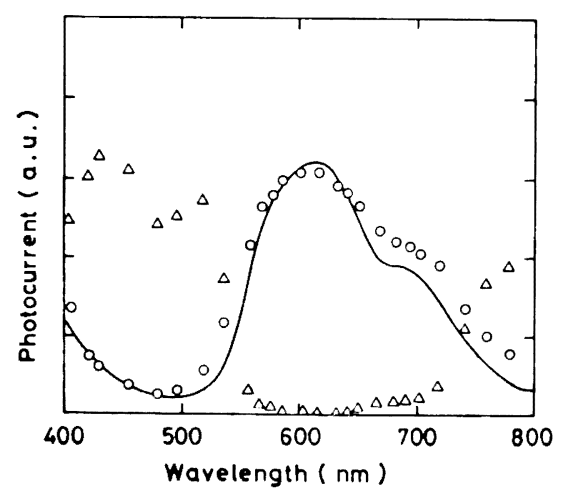

Fig. 3. Photocurrent spectra of an $\mathrm{In}_{2} \mathrm{O}_{3} / \mathrm{H}_{2} \mathrm{Pc}$ $\mathrm{PVK} / \mathrm{Al}$ cell illuminated through $\mathrm{Al}(\mathrm{O})$ and through $\mathrm{In}_{2} \mathrm{O}_{3}(\triangle)$. Absorption spectrum of a particulate $\mathrm{H}_{2} \mathrm{Pc}$ film (-).

は $F F=0.38, \eta=0.77 \%$ である.

Fig. 3 には光電流スペクトルを示す. ここでは $R_{\mathrm{L}}=$ $10^{3} \Omega$ を用いた. Al 側から光照射した場合に $\mathrm{H}_{2} \mathrm{Pc} の$ 吸収スペクトルに類似した形となり， $\operatorname{In}_{2} \mathrm{O}_{3}$ 側から光照 射した場合に $\mathrm{H}_{2} \mathrm{Pc}$ の透過スペクトルに対応した形状と なった.このことから, $\mathrm{Al}$ と $\mathrm{H}_{2} \mathrm{Pc}$ の界面近傍が光電 流発生に active な領域であることがわかる.

また暗中での電流電圧特性は，Al 側に負バイアスを かけた場合が順方向となるよらな整流性を示した。

以上の結果から,この光電池に沶いては $\mathrm{Al}$ と $\mathrm{H}_{2} \mathrm{Fc}$ の界面に, 仕事関数の差に基つくショットキーバリアが 形成されており，そこが光起電力や整流性の起源にな っていると考えられる. 寸なわち, $\mathrm{p}$ 型半導体とされる $\mathrm{H}_{2} \mathrm{Pc}$ のフェルミ準位は $\mathrm{Al}$ のそれよりも深い位膡にあ るため、この両者を接触させると Al から $\mathrm{H}_{2} \mathrm{Pc}$ の方 向人電子が流れこみ, その結果, $\mathrm{H}_{2} \mathrm{Pc}$ 表面近くに自由 キャリアの久乏した層 (depletion layer) による電位勾

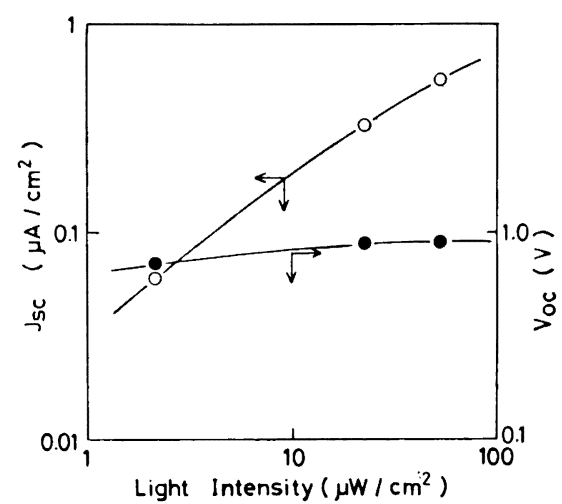

Fig. 4. Dependence of short circuit photocurrent density $\left(J_{\mathrm{sc}}\right)(O)$ and open circuit photovoltage $\left(V_{\text {oc }}\right)(O)$ on light intensity.

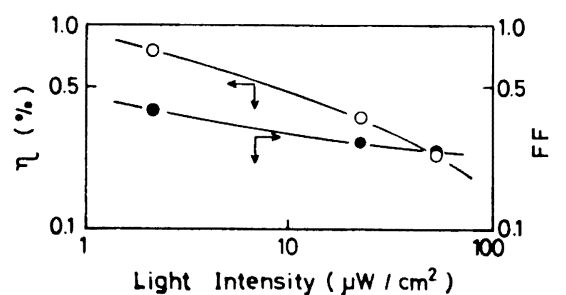

Fig.5. Dependence of energy conversion efficiency $(\eta)(\bigcirc)$ and fill factor $(F F)$ (O) on light intensity.

配が形成される. 光励起により生成した電子とホールの 対（励起子）はこの部分で解離し, 電子は $\mathrm{Al}$ 側へ, ホ 一ルは $\mathrm{In}_{2} \mathrm{O}_{3}$ 側へ移動する結果, 光電流や光起電力が 発生する.

以上のよ5な挙動及びそれに対する解釈は, 従来報告 されているフタロシアニン光電池の場合と一致してい $ろ^{8), 13), 14)}$.

Fig. 4 及び Fig. 5 には, 短絡光電流密度 $\left(J_{\mathrm{sc}}\right), V_{\mathrm{oc}}$, $F F$ 及び $\eta$ の光強度依存性を示した. $V_{\text {oc }}^{\prime}$ は光強度とと もに飽和する傾向を示す. $J_{\mathrm{Bc}}$ は, $J_{\mathrm{Bc}} \propto L^{n}$ ( $L$ は光強度) で表され， $n=0.71$ である.このように, 光強度に対し sublinear な依存性となるのは, $\mathrm{H}_{2} \mathrm{Pc}$ 中にキャリアト ラップが多数存在し, 強く励起されるとともにトラップ を通じての電子とホールの再結合が増加するためと考え られる ${ }^{15)} . F F$ が光强度とともに減少するのは, 光キャ リアの生成効率が電場の大きさに依存して扣り ${ }^{16)}$, 強励 起下ではその依存性が強くなるためである. クが光強度 とともに減少していくのは, 以上述べたように $J_{\mathrm{sc}}$ が光 強度に比例して増加しないこと, 及び $F F$ が減少するこ とが原因である。 
南・佐々木

Table 1. Effects of pretreatments of $\mathrm{H}_{2} \mathrm{Pc}$ on photovoltaic properties of particulate films ${ }^{\text {a) }}$

\begin{tabular}{clclcl}
\hline \hline $\begin{array}{c}\text { Sample } \\
\text { No. }\end{array}$ & Treatment & $\begin{array}{c}V_{\mathrm{oc}} \\
(\mathrm{V})\end{array}$ & $\begin{array}{c}J_{\mathrm{sc}} \\
\left(\mathrm{A} / \mathrm{cm}^{2}\right)\end{array}$ & $F F$ & $\begin{array}{c}\eta \\
(\%)\end{array}$ \\
\hline 1 & Untreated & 0.56 & $7.6 \times 10^{-8}$ & 0.39 & 1.0 \\
2 & Acid pasting & 0.63 & $2.6 \times 10^{-8}$ & 0.38 & 0.37 \\
3 & Sublimation & 0.65 & $4.0 \times 10^{-8}$ & 0.37 & 0.059 \\
\hline
\end{tabular}

a) $P_{\mathrm{ln}}=1.65 \mu \mathrm{W} / \mathrm{cm}^{2}$

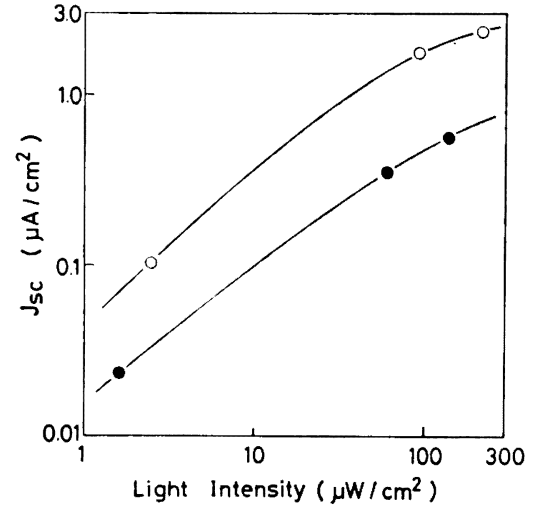

Fig. 6. Dependence of $J_{\mathrm{Bc}}$ on light intensity: untreated $\mathrm{H}_{2} \mathrm{Pc}(\mathrm{O})$ and acid-pasted $\mathrm{H}_{2} \mathrm{Pc}(\bullet)$.

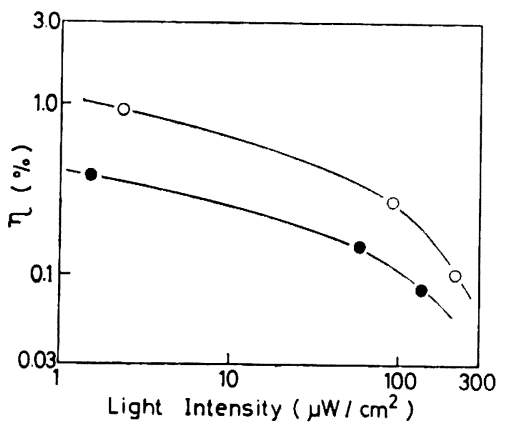

Fig. 7. Dependence of $\eta$ on light intensity: untreated $\mathrm{H}_{2} \mathrm{Pc}(\mathrm{O})$ and acid-pasted $\mathrm{H}_{2} \mathrm{Pc}(\bullet)$.

\section{$3.2 \mathrm{H}_{2} \mathrm{Pc}$ 前処理の効果}

Table 1 は, $\mathrm{H}_{2} \mathrm{Pc}$ 前処理によって, 光電池としての 各特性值がどのように変化するかを示したものである. ここでは $P_{\mathrm{In}}=1.65 \mu \mathrm{W} / \mathrm{cm}^{2}$ である. 硫酸処理 (acid pasting), 昇華精製のいずれを行った場合も，効率は未処 理のものより低下している，特に，昇華精製した場合に 著しい低下が起こる．この効率低下は， $J_{\mathrm{sc}}$ が減少して いるためである。

$\mathrm{H}_{2} \mathrm{Pc}$ を昇華精製した場合，先に述べたように非昇華 性残余物が残る。また，硫酸処理により，硫酸に溶けな い不純物及び氷溶性の不純物は除去されるはずである.

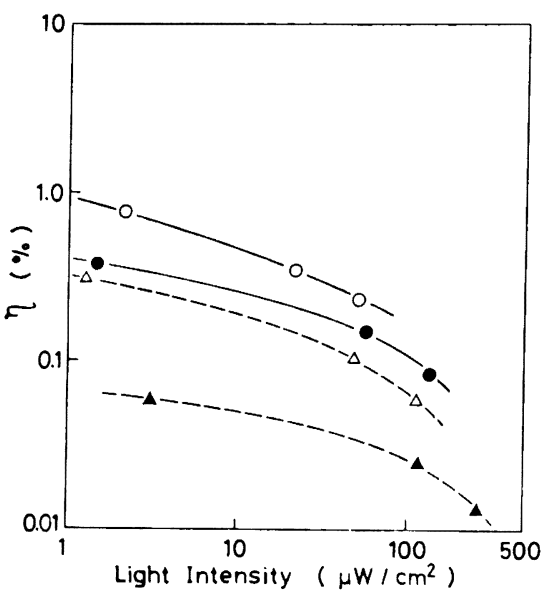

Fig. 8. Effect of ball milling on $\eta$ : before ball milling $\mathrm{H}_{2} \mathrm{Pc}$ was washed with organic solvents for 5 days $(O$ and $\bullet$ ) and for 3 weeks $(\Delta$ and $\Delta$ ) after acid pasting. Ball milling time: $0 \mathrm{~h}(\bullet$ and $\Delta), 16 \mathrm{~h}(O)$, and $30 \mathrm{~h}(\Delta)$.

このように, $\mathrm{H}_{2} \mathrm{Pc}$ 自身の純度は向上しているにもかか わらず効率が減少するのは, 今の場合, 純度以外に重要 な因子があるためである. 後で述べるボールミルの効果 と考光併せると，その因子とは， $\mathrm{H}_{2} \mathrm{Pc}$ 粒子の粒度と考 えられる。

Fig. 6 及び 7 は, Table 1 の No. 1 と 2 の試料 につき， $J_{\mathrm{sc}}$ 及び $\eta$ の光強度依存性を示したものであ る. 測定した全光強度領域に批いて，未処理の $\mathrm{H}_{2} \mathrm{Pc}$ の 方が優っている.ただし，未処理のものは，光の強いと ころで $J_{\mathrm{sc}}$ が飽和する傾向をより強く示して扰り，含有 不純物が電子とホールの再結合に関与していることを示 唆している.

一方, 志村らは, $\mathrm{SnO}_{2} / \mathrm{H}_{2} \mathrm{Pc} / \mathrm{Au}$ のサンドイッチセル に怙いて，光電流の大きさが硫酸処理によってむしろ増 大することを報告している $\mathrm{H}_{2} \mathrm{Pc}$ の原材料として何を用いるかにも依存しているも のと思われる.

次に，ボールミルの効果を Fig. 8 に示す.ここで は， 2 種の $\mathrm{H}_{2} \mathrm{Pc}$ 試料についてボールミルを試みた. 図 中で○と○は硫酸処理後の有機溶媒による洗浄を 5 日間 
で打ち切ったもの， $\Delta$ とはは洗浄夜の色が完全に消える まで 3 週間洗浄を継続したものである. いずれの場合も 16 時間あるいは 30 時間のボールミルによって効率が向 上している．また図には示していないが，昇華精製した $\mathrm{H}_{2} \mathrm{Pc}$ す 24 時間のボールミルによって効率が 5 6 倍 に向上した．これらの効率向上も，主として $J_{\mathrm{Bc}}$ の増加 によっている.

ボールミルの効果から見て， $\mathrm{H}_{2} \mathrm{Pc}$ 粒子の粒度が重要 な因子と考えられる. 事実, 光学顕徽鏡及び走查型電子 顕微鏡で観察したところ，ボールミルしたものは全体と して粒径が細かく密になり，膜中で白く抜けた部分が減 っていることがわかった．また，Talystep 1 によって 表面の粗さを調べたところ，硫酸処理しただけのものに は $1 \mu \mathrm{m}$ 程度以上の粒子がかなり多量に含まれるのに対 し、ボールミルによってそのような粗い粒子の数が著し く減少していることがわかった。

粒度が細かい之効率が向上するのは，膜が密に均質化 し，むだなく光を吸収できるようになることが一因と考 えられる. 未処理 $\mathrm{H}_{2} \mathrm{Pc}$ の効率が高いのは, 粒度が細か いことを反映している，昇華精製したものが，純度の向 上にもかかわらず効率が低下するのは， $\mathrm{H}_{2} \mathrm{Pc}$ の結晶粒 が気相から大きく成長するためである．また，Fig. 8 で， 長時間有機溶媒で洗浄したものの効率が低いのは, 有機 溶媒が結晶化を促進するためと思われる ${ }^{18)}$.

未処理の $\mathrm{H}_{2} \mathrm{Pc}$ は, 効率の点では優っているが, 経時 劣化の大きいことが久点である。一方，昇華精製した $\mathrm{H}_{2} \mathrm{Pc}$ を用いた場合, 効率は低いが性能は比較的安定し ている.このことから, 経時劣化には不純物が関与して いるものと思われる.

\section{3 蒸着膜光電池との比較}

この種の光電池の挙動を理解するため, 蒸着膜光電池 との比較を試みた．Fig. 9,10 にその結果を示す. 分散 膜光電池の方は, 硫酸処理後 16 時間ボールミルした $\mathrm{H}_{2} \mathrm{Pc}$ を用いたものである. 測定した全光強度領域で， 分散膜光電池の方が $J_{\mathrm{sc}}$ が大きく， わ高くなってい る. $V_{\mathrm{oc}}$ や FFは，注ぼ同じ位の值であった。

この結果は, 光電流発生のためには, 蒸着膜のような 均質な層よりも，微粒子が分散状態で存在する方が有利 であることを示している（ただし分散状態が粗くなり すぎると，前節で述べたよらな効率低下をもたらす.) 分 散膜と蒸着膜との主たる相違点としては， $\mathrm{H}_{2} \mathrm{Pc}$ の表面 積が考えられる. 蒸着膜の場合, $\mathrm{H}_{2} \mathrm{Pc}$ 表面は $\mathrm{Al}$ 及び $\mathrm{In}_{2} \mathrm{O}_{3}$ 雨電極との界面たけであるのに対し，分散膜では 膜中いたるところに $\mathrm{H}_{2} \mathrm{Pc}$ 粒子の表面が存在する.この ような表面積の違いが， Fig. 9 のよらな光電流值の差を あたらしていると思われる.

一般に, 有機半導体における光キャリア発生機構の一 つとして，励起子と表面との相互作用によるものが考兑

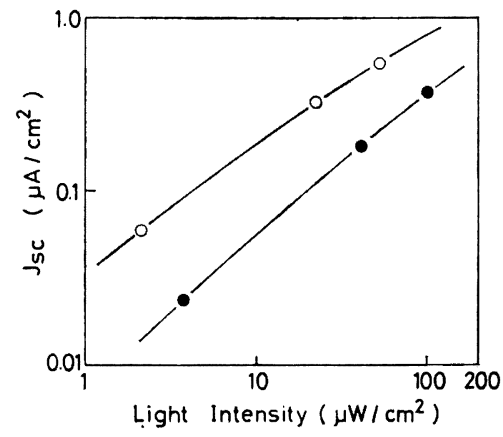

Fig. 9. Dependence of $J_{\mathrm{Bc}}$ on light intensity: a particulate $\mathrm{H}_{2} \mathrm{Pc}$ film $(\mathrm{O})$ and an evaporated $\mathrm{H}_{2} \mathrm{Pc}$ film (๑).

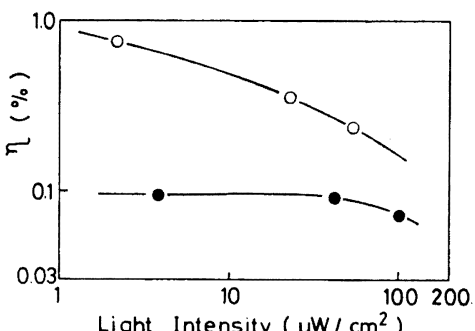

Fig. 10. Dependence of $\eta$ on light intensity: a particulate $\mathrm{H}_{2} \mathrm{Pc}$ film $(\mathrm{O})$ and an evaporated $\mathrm{H}_{2} \mathrm{Pc}$ film (๑).

られている ${ }^{19)}$. 表面は，吸着酸素，不純物，久陷などの 影響が大きく，これらが電子あるいはホールのいずれか 一方を捕獲するため, 励起子解離を促進するものと考え られる.したがって, 表面積の增大によってキャリア発 生の場が増え, 光電流の量子効率を向上させることにな る. 粒子分散膜の方が蒸着膜よりも効率が高いのは, こ のような考方方で定性的に理解できる.

前節で述べたよらなボールミルによる効率向上におい ても，単なる光学的均質性の向上だけでなく，粒子の微 細化に伴って $\mathrm{H}_{2} \mathrm{Pc}$ 表面積が増大寸ることもまた主要な 原因と考えられる。

Fig. 9 を見ると， $J_{\mathrm{sc}}$ の光強度依存性が，分散膜と蒸 着膜とでやや異なっていることがわかる. 分散膜では $J_{\mathrm{Bc}}$ が光強度の 0.71 乗に比例しているのに対し, 蒸着 膜の方は 0.86 乗であり, 光強度依存性の点では蒸着膜 の方が優っている. その結果, 蒸着膜光電池では, 光強 度に伴う効率減少が分散膜ほど顕著には現れない。この ことは、この再者の間で, キャリアトラップの性状に違 いがあることを示唆している. Hoshino は， $\varepsilon$ 型銅フタ ロシアニン粒子分散膜の熱刺激電流の測定結果から，粒 子表面にキャリアトラップが分布していることを示し $た^{200}$. 今の場合も, $\mathrm{H}_{2} \mathrm{Pc}$ 粒子表面に, 光強度依存性劣 
化の原因となるトラップが数多く存在することが考えら れる.

このように，この種の分散膜光電池では，粒子表面が 複雑な作用を及ぼす可能性があるので，表面状態の制御 が重要な検討課題である.

\section{4 結 論}

$\mathrm{H}_{2} \mathrm{Pc}$ 粒子分散膜からなる光電池について, $\mathrm{H}_{2} \mathrm{Pc}$ の 前処理条件を種々検討した結果, 効率の向上には粒度の 微細化が重要であること，また経時劣化を防ぐには純度 の向上が重要であることがわかった. 更に, 蒸着膜光電 池との比較から, 分散膜光電池では粒子表面が光キャリ ア発生に重要な役割を果していることが判明した。

謝 辞 $\mathrm{H}_{2} \mathrm{Pc}$ の処理法に関し貴重なる御助言をいた だいた，化学技術研究所鈴木茂氏，陚料の作製と測定に 御協力いたたいた，東京理科大学卒業研究生石井明氏 に感謝致します。

\section{文献}

1）高模 清, 浜川圭弘, 後川昭雄編著, “太陽光 発電”, 森北出版, 東京 $(1980)$.

2) 水島宜彦, 応用物理, 50, 325 (1981).

3）高橋 清, 浜川圭弘, 後川昭雄編著, “太陽光 発電”, 森北出版, 東京 $(1980)$, p. 297.

4) 水谷文雄, 機能材料, 2, No. 2, 46 (1982).

5) N. Minami, T. Watanabe, A. Fujishima, and K. Honda, Ber. Bunsenges. Phys. Chem., 83, 476 (1979).

6) N. Minami, J. Chem. Phys., 72, 6317 (1980).
7) N. Minami, J. Chem. Soc., Faraday Trans. 2, 印刷中. 78, 1871 (1982).

8) R. O. Loutfy and J. H. Sharp, J. Chem. Phys., 71, 1211 (1979).

9) R. O. Loutfy, L. F. McIntyre, and J.H. Sharp (Xerox), U.S. Patent 4175981 (1979).

10) R. O. Loutfy and E. R. Menzel, J. Am. Chem. Soc., 102, 4967 (1980).

11) R. O. Loutfy, J. H. Sharp, C. K. Hsiao, and R. Ho, J. Appl. Phys., 52, 5218 (1981).

12) Z. D. Popovic, J. Appl. Phys., 52, 6197 (1981).

13) A. K. Ghosh, D. L. Morel, T. Feng, R. F. Shaw, and C. A. Rowe Jr., J. Appl. Phys., 45, 230 (1974).

14) F. R. Fan and L. R. Faulkner, J. Chem. Phys., 69, 3334, 3341 (1978).

15) A. Rose, "Concepts in Photoconductivity and Allied Problems", Interscience, New York (1963), p. 38.

16) A. K. Ghosh and T. Feng, J. Appl. Phys., 49, 5982 (1978).

17）志村美知子, 馬場英夫, 電気化学および工業物 理化学, 50, 678 (1982).

18) F. H. Moser and A. L. Thomas, "Phthalocyanine Compounds", Reinhold, New York (1963), p. 161.

19) H. Inokuchi and Y. Maruyama, "Photoconductivity and Related Phenomena", J. Mort and D. M. Pai Ed., Elsevier, Amsterdam (1976), p. 158.

20) Y. Hoshino, J. Appl. Phys., 52, 5655 (1981).

Photovoltaic Properties of Phthalocyanine Particulate Films and Effects of Pretreatments of Pigment

Nobutsugu MINAMI ${ }^{* 1}$ and Kanji SASAKI ${ }^{* 1}$

${ }^{* 1}$ Research Institute for Polymers and Textiles (1-1-4, Yatabe-Higashi, Tsukuba, Ibaraki, 305 Japan)

Pretreatments of metal free phthalocyanine $\left(\mathrm{H}_{2} \mathrm{Pc}\right)$ have been found to influence the properties of photovoltaic cells produced by dispersing $\mathrm{H}_{2} \mathrm{Pc}$ particles in poly $\left(N\right.$-vinylcarbazole) films. Sulfuric-acid-treated $\mathrm{H}_{2} \mathrm{Pc}$ and sublimed $\mathrm{H}_{2} \mathrm{Pc}$ gave smaller short circuit photocurrent densities $\left(J_{\mathrm{Bc}}\right)$ and lower energy conversion efficiencies ( $\eta$ ) than did untreated $\mathrm{H}_{2} \mathrm{Pc}$; this was attributed to particle size coarsening caused by these treatments. Ball milling of $\mathrm{H}_{2} \mathrm{Pc}$ improved both $J_{\mathrm{sc}}$ and $\eta$. Impurities contained in untreated $\mathrm{H}_{2} \mathrm{Pc}$ seemed to be involved in electron-hole recombination under strong illumination and in deterioration of the cells. The fact that particulate photovoltaic cells exhibited higher efficiencies than did those consisting of evaporated $\mathrm{H}_{2} \mathrm{Pc}$ films suggested that particle surfaces play an important role in photocarrier generation.

KEY WORDS Phthalocyanine / Metal Free Phthalocyanine / Particulate Film / Photovoltaic Cell / Photovoltage / Photocurrent / Particle Size / Ball Milling /

(Received November 1, 1982: Accepted November 12, 1982)

[Kobunshi Ronbunshu, 40 (4), 211-216 (1983)] 